\title{
THE EMPIRICS OF TRADE AND GROWTH: WHERE ARE THE POLICY RECOMMENDATIONS?
}

\author{
Klaus Wälde (corresponding author) \\ University of Dresden and European Commission \\ DG ECFIN, BU1 5-179, 1160 Brussels, Belgium \\ $\unlhd$ Klaus@waelde.com 品 http://www.waelde.com

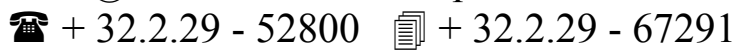

forthcoming International Economics and Economic Policy 2/3

\author{
Christina Wood* \\ The World Bank, PREM, West Africa Group, Washington DC 20433, USA
}

March 2004

\begin{abstract}
Existing literature repeatedly documented a strong correlation between trade and growth. It has also shown a causal effect of imports (though not necessarily exports) on growth in simultaneous equation models but to a lesser extent in Granger-causality tests. Export and import taxes have sometimes been found to negatively affect growth. Drawing policy conclusions from these general findings for a particular country is difficult not only because of the contradictory results but also because of potential second best world effects and the implied endogeneity of trade policy. Policy recommendations for a specific country require a careful analysis of market and institutional arrangements and can not be based on the existing cross-country literature.
\end{abstract}

Keywords: Theoretical and Empirical Trade and Growth Studies, Policy Recommendations

JEL Classification:F13 Commercial Policy; Protection; Promotion; Trade Negotiations

O1 Economic Development

* This project started while both authors were working at the World Bank. Views expressed in this paper do not necessarily represent the views of the World Bank or the institutions they are currently affiliated with. We are grateful for the financial support from the Belgian French Community's program 'Action de Recherches Concertée' 99/04-235. We would like to thank Lucas Bretschger, Shanta Deverajan, Marion Jansen, Marcelo Olarreaga, Howard Pack, Karen Pittel and Paul Welfens for helpful discussions and comments. We are especially indebted to Simon Evenett for very detailed and constructive comments. 
We find little evidence that open trade policies-in the sense of lower tariff and non-tariff barriers to trade--

are significantly associated with economic growth

Rodriguez and Rodrik (2000)

\section{INTRODUCTION}

There is an ongoing debate on whether increased trade spurs growth and industrialization, or whether it is economic growth that enables trade to increase. The implicit question with respect to developing countries is whether the major sources of growth and industrialization are external (i.e. learning through trade generally or exports or imports specifically) or internal (i.e. through human and physical capital investment and increased research and development). On one side of the debate, the phenomenal increase in trade and exports in East Asia is cited as the source of East Asia's rapid industrialization and convergence toward the developed economy level. On the other side, the reported interventionist policies of the East Asian governments (through industrial, technology and human development policies) is cited as being instrumental in shaping the comparative advantage and hence the development paths of those economies (Wade, 1990; Amsden, 1989; among others). These academic critics are joined by government officials of developing countries who stress the need for temporary protection of local firms to allow them to move up their learning curves, eventually raise their productivity and to compete internationally.

Resolving the debate on trade and growth linkages would allow developing countries to formulate trade and domestic economic policies that raise growth and induce industrialization. ${ }^{1}$ If the sources of growth are external, then developing countries should reduce the barriers to trade which restrict imports and reduce the externality effects of exporting. If, on the other hand, the critical sources of growth are internal, then developing countries need not concentrate their scarce resources on undertaking trade liberalization measures exclusively to the neglect of programs for physical capital investment and human resource development.

The objective of this literature review is to determine how the literature can inform policy makers on the choice of policy instruments. Does the empirical and theoretical literature unambiguously support, from an efficiency perspective, the case for liberalization? As a corollary, to what extent can arguments for import protection or export promotion be made? We answer these questions by (i) summarizing the empirical findings on trade and growth linkages and by (ii) investigating to what extent robust policy recommendations can be drawn from these studies. ${ }^{2}$

Other reviews of the trade and growth link or related aspects exist. They include Pack (1988, 1992), Edwards (1993) and Rodrik (1995a). While policy recommendations played some role in these reviews, they were not as explicitly treated as here. Generally, these reviews focused more on the links between trade and growth and to a lesser extent

1 While the theoretical and empirical survey below was written with a focus on developing countries, the broad themes and the findings are equally valid for industrialized countries.

2 Though an at least equally important issue, we will not discuss the effects of trade or trade policy on distributional issues. 
on the link between trade policies and growth. ${ }^{3}$ An interesting discussion of the (not so strong) link between the new growth theory and development economics is provided by Ruttan (1998). He also briefly touches upon growth and trade issues but does not focus too much on policy issues. Our paper complements these papers by summarizing the profession's empirical and theoretical knowledge about the link between trade and growth and, our main motivation for this paper, by working out the policy implications that can be drawn from these studies.

As we will show, recommending pure forms of trade policy - free trade, import protection or export promotion - would be on weak empirical and theoretical grounds. The review finds a surprising lack of convincing evidence that trade or export policies can be used to generate higher growth rates. Interestingly, precious little is known on trade policy and growth links, despite the extensive work undertaken on the issue. The empirical literature, therefore, may not be used to justify policy prescriptions of trade liberalization, import substitution or export promotion.

Several reasons underlie our findings. First, it is notoriously difficult to find simple summary statistics that capture the essence of tariff and non-tariff barriers and that are comparable across countries or over time. As a consequence, direct approaches to assess the implications of trade policy on growth are rare. Second, researchers have been unable to disentangle the impacts of trade policy from the effects of other policies (such as sound macroeconomic management) which tend to be implemented simultaneously with trade policy measures. Third, many empirical studies omit to specify theoretical frameworks on which to base the empirical modeling, rendering their findings difficult to interpret. Finally, indirect analyses of trade policy implications on growth (the vast majority of the literature) utilize methodologies that have serious limitations, yield results that are ambiguous (e.g., causality between exports and growth may run in either direction) or are highly sensitive to model specifications.

In order to investigate the extent to which empirical findings allow unambiguous policy conclusions, one needs to have several theoretical predictions in mind. Section 2 will therefore present an overview of relevant theoretical results linking trade and growth. Section 3 presents selected empirical papers and the correlations or causalities they find. We focus on five broad methodological groupings that have been used in the literature: aggregate cross country OLS regressions with trade variables; instrumental variable regressions, simultaneous equations and panel data models; Granger causality approaches; aggregate cross country OLS regressions with exogenous policy variables; and microeconomic studies of firm-level productivity in the export and non-export sectors. Under each methodology, one to several representative papers are presented, and their policy conclusions are discussed. Section 4 presents a simple theoretical model that questions the way these policy recommendations were drawn. Section 5 concludes.

\section{A THEORETICAL PERSPECTIVE ON THE LINKS BETWEEN TRADE POLICY AND GROWTH}

The main section of this paper, section 3, will be concerned with empirical studies that are focused on estimating certain trade and growth links. Policy recommendations

3 A very detailed analysis of the growth evidence in general is provided by Temple (1999). A survey that also has a certain focus on policy is by Rodriguez and Rodrik (1999). They support the general skeptic tone of our survey. 
are often inferred from these estimates. In order to be able, however, to judge how wellfounded the policy recommendations are, one needs to have several theories in mind. ${ }^{4}$ If one has only one theory in mind and the data does not contradict this theory, policy conclusions can be drawn based on this theory. If one, however, has two theories in mind and the data does not contradict the second theory either, policy conclusions can not be drawn.

It is the objective of this section to provide an overview of various theoretical predictions to facilitate interpretation of the empirical findings presented in the next section. In a sense, having these theoretical possibilities in mind makes the empirical studies afterwards tests of these theories. If all theories are rejected or if more than one theory survives, no policy conclusion can be drawn.

\subsection{STATIC EFFECTS}

\section{From trade policy to GDP}

More openness understood as lower trade barriers can affect output of an economy in a static and in a dynamic way. Consider first a static economy, e.g. a standard $2 \times 2$ Heckscher-Ohlin model where the only distortion is a tariff on the imported good. International goods prices are constant. When the country reduces the tariff on the imported good, imports rise, exports rise and GDP grows. In such an economy, one observes a positive correlation of output with exports and the cause of growth is more openness. Other sources of output growth include better exploitation of economies of scale (Krugman, 1981), which implies that exporting firms have higher productivity compared to non-exporting firms.

By contrast, (realistic) examples where more openness leads to static losses can just as easily be constructed. Imagine a Heckscher-Ohlin model as above but assume downward rigid real wages as in Brecher (1974) or any other domestic distortion as recently briefly summarized in Bhagwati (1994). More openness measured by lower tariffs that implies a lower domestic price for the labor intensive good leads to unemployment and potentially a loss in GDP and welfare. An appendix (available upon request) presents a version of Brecher (1974), adapted for developing countries.

\section{From GDP to trade}

In contrast to these trade-to-GDP links, GDP-to-trade links can be easily imagined as well. In a growing economy - in the Rybczynski theorem sense - an (exogenous) increase in an economy's capital stock leads (in a 2x2 Heckscher-Ohlin model with fixed goods prices) to an increase in the output of the capital-intensive good and a decrease of the other, the labor-intensive, good. If the country is capital-abundant vis-àvis the rest of the world, the increase in the capital stock leads to more trade (as the economy becomes more specialized). If the economy is labor-abundant, however, a growth of the economy's capital stock leads to less trade as specialization diminishes. 


\subsection{DYNAMIC EFFECTS}

\section{From trade to growth}

The new growth theory, starting with Romer (1986, 1990), Lucas (1988), Aghion and Howitt (1992) and Grossman and Helpman (1991), allows to study the link between exports and growth. ${ }^{5}$ Rivera-Batiz and Romer (1991) have studied growth effects of integration (defined as knowledge spillovers or trade in goods or both) by comparing integrated and non-integrated countries. They found two links through which integration can have an impact on growth. First, in models where growth is driven by the public good nature of knowledge spillovers that result from R\&D à la Romer (1990), integration leads to higher growth if it increases the stock of knowledge available to a country. With perfect international knowledge spillovers, countries grow faster after integration than before. As growth increases because of these spillovers, this can be interpreted as "learning by trading". In this knowledge-spillover-driven model, trade in goods per se does not have any impact on growth.

Second, in their "lab-equipment model," production is characterized by constant returns to scale in capital and the number of intermediate goods, which implies the positive long-run growth rate. This leads to a growth effect of integration as in simpler Rebelo (1991) AK models. When countries trade in intermediate goods, these goods increase productivity in $\mathrm{R} \& \mathrm{D}$ and therefore the growth rate. Here, growth increases when opening up to trade as the number of different intermediate goods rises. ${ }^{6}$

If knowledge spillovers are not perfect - imagine a developing country that can not use all the knowledge available in industrialized countries - opening up to trade leads to divergent growth paths. ${ }^{7}$ As shown by Grossman and Helpman (1991, ch. 8), the growth rate of the economy that was rich at the moment of trade liberalization will increase while the growth rate of the economy that was poor will fall to zero. From a welfare perspective, the poor country might even be worse off under free trade. A similar instability result for the growth equilibrium of Rivera-Batiz and Romer (1991) was established by Devereux and Lapham (1994). Stokey (1991) also shows, in a model where human capital accumulation drives long-run growth, that free trade can lead to less growth which might imply welfare losses. Tang and Wälde (2000) show that international trade can imply welfare losses and a reduction in the rate of growth if trade causes competition to become too fierce. ${ }^{8}$

5 For an extension of Aghion and Howitt (1992), cf. Wälde (1999).

6 It should be kept in mind that few are really happy with an implication of this result which is the scale-effect: The larger a country (as measured by the number of workers or its stock of human capital), the higher its growth rate. This implication would predict that countries like India or China should grow faster than Singapore or Switzerland. It should also be noted, however, that none of these countries are closed economies and only in this case, this qualification holds. More recent papers by Segerstrom (1998) and Young (1998) have resolved the scale-effect problem.

7 The same is true of course also for regions, e.g. within Europe or within a country. Cf. e.g. Bretschger (1999).

8 More channels have been identified in the literature how international capital flows or integration affect growth (e.g. Bretschger and Steger, this issue, or Smulders, this issue). The ones mentioned above are enough, however, to make our main argument here. 


\section{The ambiguous way from trade policy to growth}

Let us now turn to the dynamic effects of trade policy. Generally speaking, the effects of tariffs on growth are ambiguous and depend on the effect of tariffs on factors allocated to R\&D. Whatever policy leads to more employment in R\&D will lead to more growth (this is an immediate implication of the setup of new growth models, cf. e.g. Grossman and Helpman, 1991, 1995, ch. 4.1). Imagine a small open economy consisting of an R\&D sector and two final goods sectors. This economy uses two factors of production and let the R\&D sector, which is the non-traded goods sector, be the most human capital intensive sector. When the price of the human capital intensive final good goes down, the human capital intensive final good sector shrinks and human capital becomes less expensive. Factors of production move both to the other final good sector and the R\&D sector. As human capital becomes cheaper relative to labor and the $\mathrm{R} \& \mathrm{D}$ sector is the most human capital intensive sector, any decrease in the price of the human capital intensive final good sector implies higher growth. By contrast, any decrease in the price of the labor intensive final good sector implies lower growth.

Walz (1997) provides a nice link between growth theory and static trade theory (cf. also Walz, 1998). It is known from static trade theory that trade diversion in trade-bloc models reduces welfare and trade creation increases welfare. Walz shows in a threecountry growth model that a reduction in trade barriers leads to a reduction in growth rates if reducing barriers implies trade diversion whereas it leads to an increase in growth rates if there is trade creation.

\section{From growth to trade}

In contrast to the examples where changes in trade policy affect growth, one can just as easily think of reverse causality links from growth to trade. The starting point of such a line of argument are two small open economies which differ in their growth rates because agents in one economy are more patient than in the other or because one economy pays $R \& D$ subsidies and the other does not. $R \& D$ subsidies lead to more allocation of resources to the R\&D sector, to a higher relative price of the factor intensively used in $\mathrm{R} \& \mathrm{D}$, say human capital, and a relative specialization of the economy in the good that uses human capital less intensively. This induces more trade with the rest of the world as it purchases more of the non-specialized good.

An alternative argument based on a diversified final good can be made as well. Imagine an economy with an R\&D sector and a final consumption good sector and embed it in a world economy consisting of two such economies, as e.g. in Grossman and Helpman (1991, ch. 9). An increase in R\&D subsidies in one country (or in both) will increase the world innovation rate and a higher growth rate of exports. Exports (in goods) per se, however, do not have any impact on growth. ${ }^{9}$ 


\section{EMPIRICAL STUDIES AND POLICY IMPLICATIONS}

The previous section has shown that theory provides a broad set of predictions. Different assumptions naturally lead to different results. The interaction of international trade and economic growth takes place via many different channels. It is the task of empirical work to identify which are the relevant ones.

This section gives an overview of empirical studies that investigate the link between trade and growth. They are classified according to the method used, as the methodological approach is crucial for judging how well-founded the deduced policy conclusions are. Each method will be illustrated by a few representative studies. While the results of each study will be presented, our main interest lies in finding an answer to the question: Which policy recommendations can be drawn from these studies?

We use two criteria for judging whether an empirical study is informative about trade policy: First, are results robust in the sense of Levine and Renelt (1992), and, second, to what extent do empirical findings imply an unambiguous theoretical interpretation. When results are not robust or several theoretical interpretations are possible, no policy conclusions can be drawn.

\subsection{CROSS-COUNTRY OLS GROWTH REGRESSIONS}

This is by far the most prevalent methodology utilized to provide evidence that increased exports are important for domestic economic growth. In these studies ${ }^{10}$, twoto-three-decade averages of GDP growth or GDP per capita growth are regressed on a number of variables including measures of openness or exports. These measures are mostly the average trade to GDP ratio though some authors distinguish between the export to GDP and the import to GDP ratio. ${ }^{11}$ It is typically found that the coefficient on the trade variable is positive and significant.

There are two major problems with this approach. First, Levine and Renelt (1992) showed that almost all relationships of macroeconomic variables with growth are not robust. ${ }^{12}$ Coefficients reported in the literature change sign when certain regressors are added or removed. Their findings apply to the question at hand as well. Trade or exchange rate indicators are not robustly correlated with growth. Levine and Renelt do find, however, that growth and the share of investment in GDP are robustly correlated as is the investment share with the trade to output ratio. As they note themselves, this does not imply a causality result, which leads to our other concern with this approach. ${ }^{13}$

Second, ignoring lack of robustness for the moment, one should then query what the cross-country regressions mean, assuming they are valid. An interpretation that can be

Various references are in e.g. Pack and Page (1994).

One could ask which indicator is best suited to capture trade openness and trade policy. Some authors argue that measures used in the literature all roughly capture the same aspects and could therefore be used almost interchangeably (Harrison, 1996; Edwards, 1998) while others argue that almost all openness indicators are pairwise uncorrelated (Pritchett, 1996).

12 A "robust" relationship is one that is statistically significant and of the theoretically predicted sign when the conditioning set of variables in the regression changes.

13 Sala-i-Martin (1997) argues that Levine and Renelt's approach (based on Leamer, 1985) is too strict and proposes a weaker test for robustness. 
given, and which is indeed often given, is that growth is positively affected by exports. Exports lead to higher productivity growth as firms learn from foreign trade partners about better technologies or better organizational setups. Having the theoretical examples given above in mind, it can just as easily be the case that economic growth leads to more exports. Given these ambiguities in interpretation, trade policies can not be deduced from these studies. ${ }^{14}$

\subsection{SIMULTANEOUS EQUATIONS, INSTRUMENTAL VARIABLES AND PANEL DATA MODELS}

Esfahani (1991) took the endogeneity of exports into consideration and estimated a simultaneous equation model. The dependent variables are per-capita GDP growth, the product of the share of exports in GDP and the growth rate of per-capita exports, and the product of the share of imports in GDP and the per-capita growth rate of imports. Further, in order to avoid other endogeneity problems, he used two gravity-model-type equations to replace the share of imports and the share of exports in GDP in his three equation simultaneous equation system.

Two aspects of this paper are especially notable. First, all regression equations are explicitly derived from production functions. This gives an immediate interpretation of the regression coefficients. It becomes clear, for example, that including an export ratio as explanatory variable implies the assumption (according to Esfahani's setup) that either exporting has a positive externality on productivity in the domestic good sector or that the country is foreign currency constrained.

Second, in terms of results, the coefficient on exports becomes insignificant whenever imports are included as a regressor. All the explanatory power for per-capita GDP growth comes from the import variable. Esfahani's interpretation of his results are that while the efficiency-enhancing role of exports is weak, exports do play an important role in easing the import constraints of semi-industrial economies. Hence, if exports play a role, then only this indirect one; it seems to be the availability of technologically superior import goods that increase growth.

A similar conclusion is reached by Lee (1995). He regresses per capita GDP growth on various variables, including the ratio of imported capital goods to domestically produced capital goods (computed as the difference between domestic investment and imported capital goods). Using land size, distance from trade partners and the tariff rate $^{15}$ as instruments for possibly endogenous imports, he finds a positive and significant impact of his import ratio on growth.

Frankel, Romer and Cyrus (1996) (cf. also Frankel and Romer, 1999) use instrumental variables as a means of addressing the perceived simultaneity problem. They base their regression equation on Mankiw, Romer and Weil (1992) where the dependent variable is GDP per capita (and not growth of GDP per capita). Mankiw, Romer and Weil have derived their specification from the steady state predictions of a Solow growth model with a Cobb-Douglas production function and exogenous

Apart from these basic problems, results for a certain dataset (a specific set of countries and a specific period of time) does not necessarily allow for a generalization across time and space. Vamvakidis (2002) has shown that findings on trade and growth differ considerably between the first and second half of the $20^{\text {th }}$ century. For 1920 to 1940 a negative correlation shows up and positive correlations are only a recent phenomenon.

15 Lee (1993) explored the links between trade barriers and growth further. It will be discussed in section 3.4 below. 
technological progress and population growth. Frankel, Romer and Cyrus extend the Mankiw-Romer-Weil regression by adding the trade to GDP ratio (exports plus imports divided by GDP) as an additional regressor (without, unfortunately, providing a thorough discussion of the foundations for this extension). The instrument used for the trade to GDP ratio is the predicted trade to GDP ratio of their trade gravity model. They find that the coefficient on trade flows is positive (and even larger than the OLS estimates).

The question then arises how to explain trade to GDP ratios in order to find out how this trade to GDP ratio can be influenced. Frankel, Romer and Cyrus argue that "in most cases, the contribution of openness to growth is a contribution of trade as predicted by the gravity model; thus it cannot be attributed to policies" (p. $14-15)$. This argument is not based on direct policy measures, however. The gravity model they use to predict the trade ratio does not contain measures of tariff barriers. More direct evidence would therefore be useful. This paper also finds that it cannot reject the hypothesis that the OLS and IV estimates are equal, from which they infer that the problem of simultaneity in the trade growth literature may not be as much of a problem as generally believed.

Easterly, Loayza and Montiel's (1997) paper is noteworthy as it uses panel data to tackle (among other things) the endogeneity problem. They find that their openness regressor (trade share of GDP) is significant. İscan (1998) also undertakes a panel study and focuses on Mexico. He finds short-term positive effects of trade liberalization on productivity in the manufacturing industry but also that in the long run no significant effects can be found. No attempt is made in either of these studies, given that the main focus is on macroeconomic reforms or on productivity per se, to look at the link between trade policy variables and growth.

The policy implications of these studies seem to be clear. As trade, measured by exports plus imports or only by imports, once endogeneity is appropriately taken into consideration, continues to have a statistically significant positive impact on growth, any measures that promote trade seem advisable. As one should generally expect that e.g. lower import tariffs lead to higher imports, a reduction in tariffs seems beneficial. (For empirical evidence, cf. Rodrik, 1998, discussed in section 3.4.)

There are three caveats to the policy conclusion of free trade in the sense of zero import tariffs. First, the robustness issue has not always been addressed with sufficient care. Second, these studies do not include policy variables as explanatory variables (cf. section 3.5). Even if trade is significantly linked to growth, how can policy makers influence trade? Finally, these empirical findings do not distinguish between competing theories. As section 4 will show, these results are consistent with a world where a reduction in trade tariffs does not lead to higher growth.

\subsection{Granger Causality Tests}

Jung and Marshall (1985) were among the first (if not the first) to question simple conclusions from OLS regressions. For the period of 1950 to 1981, they find the direction of causality between exports and growth to be inconclusive, with results ranging from exports that cause growth (Indonesia) and growth causes exports (Thailand) to exports that yield less growth (Korea) and no causal relationship at all (Philippines and Taiwan). A paper by Bradford and Chawkin (1993), which included investment as an explanatory variable, was similarly inconclusive. The link between investment and growth was shown to be more significant than that from exports to growth (as also found by Levine and Renelt, 1992), suggesting a greater relevance of internal over external sources of growth. 
Harrison (1996) studies the effects of trade and openness on growth using panel data and compares predictions of several measures of trade and openness. When she undertakes Granger causality tests, she finds that openness and growth cause each other in both directions. She concludes that "the direction of causality between openness and growth is by no means resolved".

Rodrik (1995b) studies four countries (Korea, Taiwan, Chile and Turkey) and presents very briefly Granger causality tests (p.9) between the share of investment in GDP and the share of exports plus imports in GDP. He finds, suggesting possibly country specific aspects, no unambiguous links. In Korea investment has Grangercaused trade while in Taiwan investment has Granger-caused trade and trade has Granger-caused investment. No causality could be detected for either direction in Chile and Turkey. He then highlights the mechanism of investment-led growth that yields higher exports in a simple model: If a country is credit constrained (Chenery, Bruno and McKinnon's argument of section 2.2), the value of exports must equal the value of imports for a certain period. If investment goods are imported (as they are superior than domestic investment goods), a subsidy to investment increases imports and growth and, by the trade balance constraint, exports.

The concept of Granger causality in itself does not immediately yield insight into basic economic mechanisms at work. Apart from this, the long length of time series data required for such causality tests to be meaningful renders this approach irrelevant for the time being. ${ }^{16}$ An additional deficiency is the lack of theoretical underpinnings of this methodology. Furthermore, even resolving the question of causality in the Granger sense would not give unambiguous recommendations concerning policy. Even if exports unambiguously preceded growth, what would be the right measures to increase exports and, more importantly and more difficult to answer: are there market failures that justify intervention?

\subsection{Microstudies}

Various authors have expressed hopes that causality questions and other questions of the growth and trade debate could be answered more convincingly when studying micro data (Edwards, 1995; Hutchinson and Singh, 1992; among others). Recent advances in methodology and computing capabilities have yielded a small but growing micro literature. Micro-level studies in general investigate differences in productivity and economic behavior between exporting and non-exporting firms. In contrast with studies using aggregate macro variables, micro-level analyses tend to be much less supportive of the exports-led growth view.

Clerides et. al. (1998) start from the observation that exporting firms are more productive than non-exporting firms. They then investigate whether firms (in their samples from Columbia, Mexico, and Morocco) export because they are productive or whether they are productive because they export. They look at the evolution of productivity of firms three years before they started to export to three years afterwards. Their main finding is that firms are first productive and then start exporting rather than the other way round: They find no evidence that exporting firms become more productive while exporting. It is therefore self-selection of productive firms into the 
export sector that explains the positive productivity-export correlation. ${ }^{17}$ They also find that the presence of exporters in some cases makes it easier for domestically-oriented firms to break into export markets (signaling that externalities are present).

Aw, Chen and Roberts (1997) utilize panel data from Taiwan to assess the links between productivity and the transition patterns of firms in and out of operation, or between the export and domestic markets. In particular, they assess whether transition patterns reflect underlying differences in firm productivity. They find that both the domestic and export markets sort high productivity firms from low productivity firms, and that the export sector has a tougher screen. As in Clerides et. al. (1998), firms that export exhibit higher productivity than other firms in the economy. Aw, Chen and Roberts also found evidence of industry-wide externalities and positive productivity trends in a number of manufacturing industry sectors, suggesting a common improvement in worker quality and infrastructure, rather than individual firm actions as a source of higher efficiency.

\subsection{Cross-Country OLS Growth Regressions With Exogenous Policy VARIABLES}

A shortcoming of all studies presented so far is the lack of an explicit consideration of trade policy instruments. A more convincing basis for trade policy recommendations could be provided if trade policy variables were included in regressions. This would, at least indirectly, allow to evaluate the trade-off between distortions through import tariffs and distortions through alternative sources for government revenue. ${ }^{18}$

Sachs and Warner (1997) focus their attention on African economies and run an OLS regression of several explanatory variables including an openness index on the growth of per capita GDP. Their openness index is from Sachs and Warner (1995) and is constructed as a zero-one variable. They characterize an economy as closed if at least one out of five characteristics holds. ${ }^{19}$ The objection to this measure is that it might just measure good policies in general and not openness. Sachs and Warner admit themselves that "the reason openness affects the level of steady-state income is a matter of ongoing research" (p. 346). With this limitation in mind, Sachs and Warner find that this measure is positively associated with growth. They estimate that the annual growth rate of the average African country that moves from a closed regime to a completely open regime would increase by 2.2 percentage points. The effect of openness is somewhat higher for poor countries than for countries with income above the mean.

Rodrik (1998) performs a detailed analysis of trade policy and economic growth for Sub-Saharan African countries. Apart from an analysis of trade per se, he investigates the Sachs and Warner openness index in more detail. He shows that this index, while having a positive and significant coefficient for a sample that includes "all" countries of the world, becomes insignificant when the sample of countries is restricted to sub-

Similar results were obtained by Bernard and Jensen (1999) who study a sample of US manufacturing firms.

18 An investigation along these lines would be even more important when evaluating the effects of export subsidies.

19 (i) Non-tariff barriers cover $40 \%$ or more of trade, (ii) the average tariff rate is $40 \%$ or more, (iii) a black market exchange rate that is $20 \%$ or more below the official exchange rates in the 1970 s or 1980 s, (iv) a socialist economic system and (v) a state monopoly on major exports. 
Saharan Africa and the entire period 1965-1990 is studied. Studying three subperiods $(1964$ - 1974, 1975 - 1984, 1985 - 1994) shows that this index becomes significant and positive again. Yet, it does not have a significant impact on exports per se (when regressing exports on country size, GDP per capita, this index and other determinants) which leads Rodrik to the conclusion that this index really measures general macroeconomic policies and not trade policies.

In his analysis of determinants of trade shares (Table 9), Rodrik regresses the export to GDP ratio and the imports to GDP ratio (averaged over 1964 to 1994) on various determinants, including export and import taxes (export tax revenues divided by total exports and import tax revenues divided by total imports). Higher export and import taxes reduce exports and imports, respectively. In an OLS growth regression (Table 13), only export taxes have a significant (negative) impact on growth. ${ }^{20}$

Overall, these studies appear to be potentially the most informative ones. Regressing growth rates on almost perfectly exogenous policy instruments allows to best judge the effect of these instruments on growth. ${ }^{21}$ Given the finding of Rodrik on the Sachs and Warner index, however, the conclusions of Sachs and Warner seem premature. The findings of Rodrik on the link between export and import taxes on trade and partially on growth show that low export taxes contribute to growth while low import taxes do not. This constitutes an unfortunate contradicting finding to Esfahani and Lee (1995). The policy discussion is therefore left without much input.

The most careful study we could find in this context appears to be Lee (1993). His growth regression equation is derived from an AK growth model. This model implies that regressors are not the tariff rates or the black market premium itself but the product of a measure of trade openness and these measures. He uses as his basic data source the Summers and Heston data set and collects information on tariff rates from a variety of sources. He interprets his findings such that tariff rates do have a significant negative impact on economic growth.

Doubt is cast on Lee's findings by the thorough and comprehensive study of Yanikkaya (2003). He analyses the effects of trade on growth by both using trade volume measures (generally positive and significant) and trade restriction measures (generally also positive and significant) as indicators of free trade. He argues that these findings are consistent with theory in that "restrictions on trade can benefit a country depending on $\langle\ldots\rangle$ whether a country has comparative advantage in those sectors that are receiving protection" (p. 84). These findings are also consistent with the many possible effects of trade on growth as discussed in the theory section 2 in the present paper.

In a shorter perspective (a pooled OLS regression of three subperiods, each one decade long), export taxes become insignificant. This, however, might more be due to the unpredictability of growth rates in the short run. discussion. It should be socially efficient to reduce trade barriers in "good times" of high growth; political economy considerations, however, suggest that trade liberalization will be undertaken in bad times when the pressure on the government is high enough. 


\section{ON THE ENDOGENEITY OF TRADE POLICY}

Our survey of empirical studies on the link of trade and growth has shown so far that despite improved methodological approaches, the only direct evidence that trade liberalization, in the sense of reducing import and export tariffs, leads to higher growth is provided by Lee (1993). Despite the usual concerns as e.g. robustness, we assume in this section that Lee's finding of a negative significant causal relationship from tariffs to growth is true. This section will now argue that even in this case no general policy recommendations can be drawn from this finding. We provide a straightforward interpretation of this finding showing that no trade policy recommendations can be given without taking second best world effects into account. In other words, trade policy recommendations for a specific country crucially depend on the functioning of domestic markets of this particular country. Policy makers should be very careful about generalizations.

Imagine a set of countries, as in Mayer (1974), with two sectors and two factors of production, labor and capital, of which capital is sector specific. Assume further some domestic distortion, which, for simplicity, we model here as the wage rigidities à la Brecher (1974), $w_{L_{i}} \geq \bar{w}_{L_{i}}$. It should be kept in mind that this is just a convenient example representing other potentially more complex market and institutional failures. Such a model can be summarized in one equilibrium condition, the equality of value marginal productivities of labor across sectors, $q_{X} X_{L_{X}}=(1+\tau) q_{Y} Y_{L_{Y}}$. International goods prices are denoted by $q_{X}$ and $q_{Y}$ respectively, $\tau$ stands for the tariff rate on good $Y$, and subscripts $L_{X}$ and $L_{Y}$ denote marginal productivities. As can be seen, domestic prices are determined internationally and through the import tariff $\tau$. The link between the tariff rate and GDP of such an economy is depicted in figure 1. (More details are contained in an appendix available upon request).

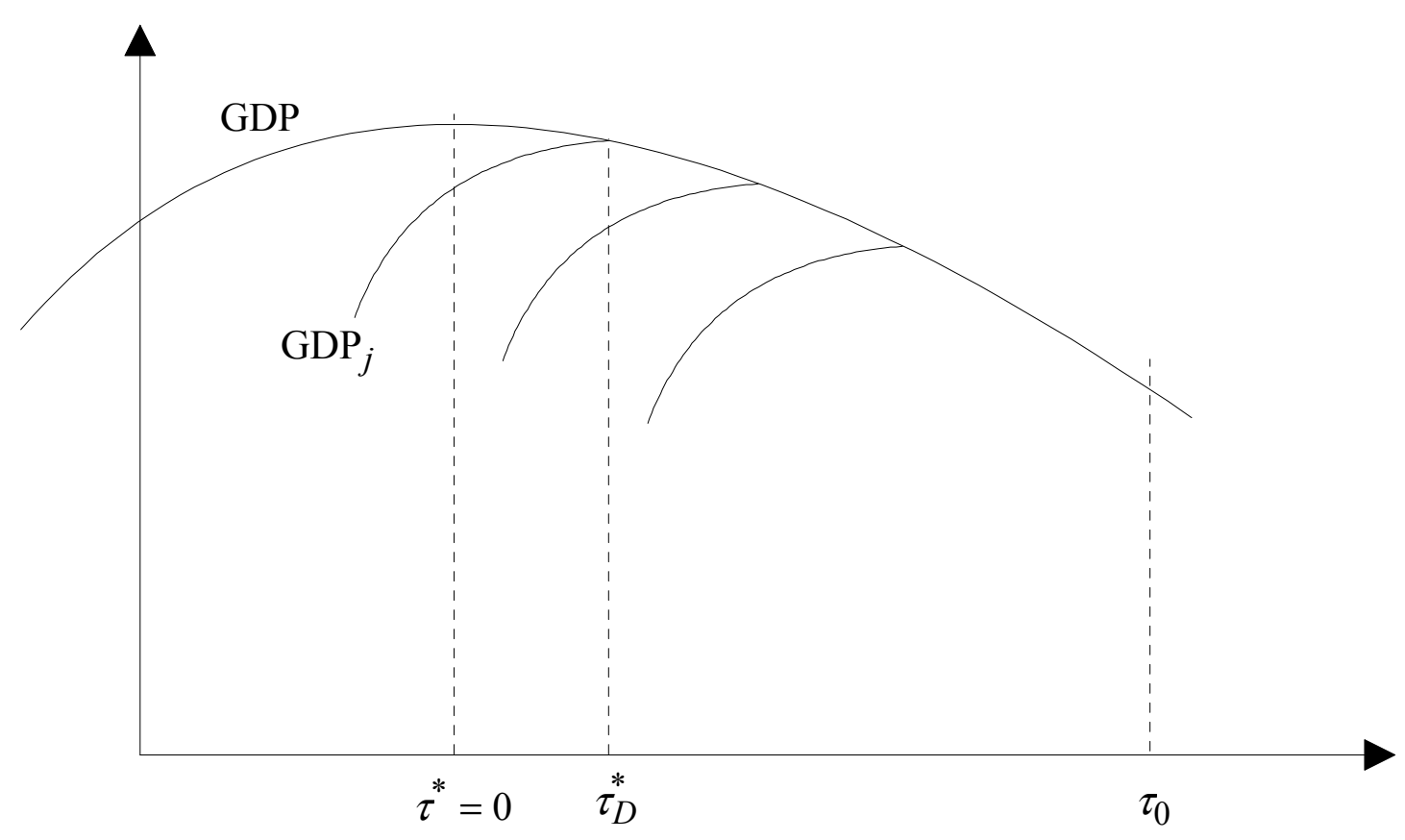

Figure 1: Tariffs and GDP 
A distortion free economy has the highest potential GDP, shown here by the line denoted GDP. GDP is highest when the tariff rate equals zero. Considering a country with some distortion, its GDP will also initially rise, starting at $\tau_{0}$, when the tariff rate decreases, but it will reach its maximum earlier than a distortion free economy. Its GDP is exactly the same as the GDP of a distortion free economy, but, once the distortion becomes relevant, it falls earlier, as shown by $\mathrm{GDP}_{j}$.

Now assume all countries perform a constrained optimal economic policy, which means that the countries with wage rigidities take those as given. The set of countries with perfect markets will then have zero tariffs and a high GDP. The set of countries with the wage distortion will set some tariffs and have a lower GDP.

Imagine an econometrician that gathers data for all countries at two points in time, before the liberalization, where all countries have the same tariff rate $\tau_{0}$, and after the liberalization. Countries with no distortions will have a higher growth rate between these two points in time than countries with a domestic distortion. The econometrician now runs a growth regression with the post-liberalization tariff rates (or the difference between the pre- and post-liberalization tariff) as an exogenous variable. The outcome of the regression will be that tariffs have a negative significant impact on growth.

If an economic advisor now recommends to the distortion countries that, because the regression has shown that high tariffs are detrimental to growth, to lower the tariffs, the outcome will be that these countries are worse off after lowering tariffs due to the wage rigidity.

This "anecdote" has two implications, both for economic research and for policy advice. In either cases, it simply means that tariff rates are endogenous. They might be high simply because there are rents to be gained and they are not optimal from a social perspective; or they are optimal given current market and institutional setups. The best policy advice is then of course to understand the reasons of the rigidity (or any other domestic institutional or market failure, of which, as was stressed, the wage rigidity is only an example) and try to find solutions to that. Too little effort seems to be undertaken in this direction, both in research and in policy advice.

\section{CONCLUSION}

The study started out with the question whether trade is good for growth. This is the central question to many policy discussions. If trade is good for growth, the argument goes, countries should liberalize trade. The implicit argument is that liberalization leads to more trade and therefore to more growth.

Looking at the empirical support for this argument, it turned out that the line of reasoning behind the argument is not sufficiently stringent. If one wants to understand the effects of trade policy on economic growth, empirical evidence on the link between trade policy instruments and economic growth has to be provided. Empirical studies should therefore investigate the link between lower tariffs or non-tariff barriers for imports or export subsidies for exports and the volume of imports and exports. Once this link is empirically established, a link between volumes of exports or imports and growth can be shown.

The existing literature is surprisingly quiet on the link between trade policy instruments and economic growth. There are many studies that use OLS regressions and establish a strong correlation between exports and growth or imports and growth. Apart 
from the missing link to trade instruments, they do not give information on causality. Is there more growth because of more imports or more imports because of more growth?

Studies that control for the endogeneity of exports or imports sometimes find that exports cause growth but sometimes also find reverse causality. The empirical picture is therefore mixed - which is not surprising, given the different causalities that can be imagined from a theoretical perspective.

Even if one accepts imports as causal to more economic growth, existing empirical studies leave open the question of how changes in trade instruments affect exports or imports. One should clearly expect that lowering tariffs should lead to more imports. But there is few empirical evidence that a lower tariff would then also lead to higher growth. Recent work even points in the other direction. Finally, theoretical arguments based on second-best world setups with tariffs being optimally set (and therefore being endogenous) clearly show that an abrupt reduction of tariffs is not necessarily welfare enhancing. ${ }^{22}$

Looking forward, the theoretical considerations in section 4 suggest that nonlinearities in the effects that tariffs have on growth should be taken into account. Further, when trade barriers are viewed as the outcome of a political process, they are clearly endogenous (Baier and Bergstrand, forthcoming). Empirical studies that take these aspects into account would be one step further towards a quantitative analysis of the effects of trade on growth that can be trusted and on which policy recommendations can be based on.

\section{REFERENCES}

Amsden, A. H., 1989, Asia's Next Giant: South Korea and Late Industrialization. New York: Oxford University Press.

Aw, B. Y., and G. Batra, 1998, Technology Capability and Firm Efficiency in Taiwan (China). The World Bank Economic Review 12: 59 - 79.

Aw, B. Y., S. Chung, and M. Roberts, 1998, Productivity and the Decision to Export:

Micro Evidence from Taiwan and South Korea. NBER Working Paper 6558.

Baier, S. L. and Bergstrand, J., forthcoming, Economic Determinants of Free Trade Agreements. Journal of International Economics

Bernard, A. B. and J. B. Jensen, 1999, Exporting and Productivity. Mimeo, Yale and Carnegie Mellon University.

Bhagwati, J., 1994, Free Trade: Old and New Challenges. Economic Journal 104: 231 246.

Bradford, C. and N. Chakwin, 1993, Alternative Explanations of the Trade-Output Correlation in the East Asian Economies. OECD Development Centre Technical Paper No. 87.

Brecher, R., 1974, Minimum Wage Rates and the Pure Theory of International Trade. Quarterly Journal of Economics 88: 98 - 116.

Bretschger, L., 1999, Knowledge Diffusion and the Development of Regions, Annals of Regional Science 33:251-268.

22 This is to some extent taken into account in policy work. The WTO uses the term "coherence" in the sense of "policy coherence necessary to make the most out of trade liberalization". See e.g. WTO (2004). 
Bretschger, L. and T.M. Steger, this issue, The Dynamics of Economic Integration: Theory and Policy. International Economics and Economic Policy 2/3.

Clerides, S., S. Lach and J. Tybout, 1998, Is Learning by Exporting Important? MicroDynamic Evidence from Columbia, Mexico, and Morocco. Quarterly Journal of Economics 113: 903 - 947.

Devereux, M. B. and B. J. Lapham, 1994, The Stability of Economic Integration and Endogenous Growth. Quarterly Journal of Economics 109: 299 - 305.

Easterly, W., N. Loayza and P. Montiel, 1997, Has Latin America's Post-Reform Growth been Disappointing? Journal of International Economics 43: 287 - 311.

Edwards, S., 1993, Openness, Trade Liberalization and Growth in Developing Countries. Journal of Economic Literature 31: 1358 - 1393.

Edwards, S., 1998, Openness, Productivity and Growth: What Do We Really Know? Economic Journal 108: 383 - 398.

Esfahani, H. S, 1991, Exports, Imports, and Economic Growth in Semi-Industrialized Countries. Journal of Development Economics 35: 93 - 116.

Frankel, J. A. and D. Romer, 1999, Does Trade Cause Growth? American Economic Review 89: 379 - 399.

Frankel, J. A., Romer, D. and T. Cyrus, 1996, Trade and Growth in East Asian Countries: Cause and Effect? NBER Working Paper 5732.

Granger, C., 1969, Investigating Causal Relations by Econometric Models and Cross Spectral Methods. Econometrica 37: 424 - 438.

Grossman, G. M. and E. Helpman, 1995, Technology and Trade. In Grossman, G. M. and Rogoff, K. (eds.) Handbook of International Economics, Vol III. Amsterdam, Elsevier.

Grossman, G. M. and E. Helpman, 1991, Innovation and Growth in the Global Economy. Cambridge, MA: MIT Press.

Harrison, A., 1996, Openness and Growth: A Time-Series, Cross-Country Analysis for Developing Countries. Journal of Development Economics 48: 419 - 447.

Hutchinson, M. and N. Singh, 1992, Exports, Non-Exports and Externalities: A Granger Causality Approach. International Economic Journal 6 (2): 79 - 94.

İscan, T., 1998, Trade Liberalization and Productivity: A Panel Study of the Mexican Manufacturing Industry. Journal of Development Studies 34, 5: 123 - 148.

Jung, S. W. and P. J. Marshall, 1985, Exports, Growth and Causality in Developing Countries. Journal of Development Economics 18: 1 - 12.

Krugman, P., 1981, Intraindustry specialization and the gains from trade. Journal of Political Economy 89: 959 - 973.

Leamer, E. E., 1985, Sensitivity Analyses Would Help. American Economic Review 57: $308-313$.

Lee, J. W., 1993, International Trade, Distortions, and Long-Run Economic Growth. IMF Staff Papers 40: 299 - 328.

Lee, J. W., 1995, Capital Goods Imports and Long-Run Growth. Journal of Development Economics 48: 91 - 110.

Levine, R. and D. Renelt, 1992, A Sensitivity Analysis of Cross-Country Growth Regressions. American Economic Review 82: 942 - 963.

Lucas, R. E., 1988, On the mechanics of economic development. Journal of Monetary Economics 22: 3 - 42.

Mankiw, N. G., D. Romer and D. N. Weil, 1992, A Contribution to the Empirics of Economic Growth. Quarterly Journal of Economics 107 (2): 407 - 437

McKenzie, M. D., 1999, The Impact of Exchange Rate Volatility on International Trade Flows. Journal of Economic Surveys 13: 71 - 106. 
Pack, H. and J. M. Page, 1994, Accumulation, Exports, and Growth in the HighPerforming Asian Economies. Carnegie-Rochester Conference Series on Public Policy 40: 199 - 236.

Pack, H., 1988, Industrialization and Trade. In Chenery, N. and T. N. Srinivasan, (eds.), Handbook of Development Economics, Vol. I. Amsterdam, Elsevier.

Pack, H., 1992, Learning and Productivity Changes in Developing Countries. In Helleiner, G. K. (ed.) Trade Policy, Industrialization and Development: New Prospectives. Oxford: Clarendon Press.

Pritchett, L., 1996, Measuring Outward Orientation in LDCs: Can It Be Done? Journal of Development Economics 49: 307 - 335.

Rebelo, S., 1991, Long-Run Policy Analysis and Long-Run Growth. Journal of Political Economy 99: 500 - 521.

Rivera-Batiz, L. A. and P. M. Romer, 1991, Economic Integration and Endogenous Growth. The Quarterly Journal of Economics 106: 531 - 555.

Rodriguez, F. and D. Rodrik, 2000, Trade Policy and Economic Growth: A Skeptic's Guide to the Cross-National Literature. In Ben Bernanke and Kenneth S. Rogoff (eds.) Macroeconomics Annual 2000, MIT Press, Cambridge, MA, 2001.

Rodrik, D., 1995a, Trade and Industrial Policy Reform. In Behrman, J. and T. N. Srinivasan, (eds.), Handbook of Development Economics, Vol. III. Amsterdam, Elsevier.

Rodrik, D., 1995b, Trade Strategy, Investment and Exports: Another Look at East Asia. NBER Working Paper 5399.

Rodrik, D., 1998, Trade Policy and Economic Performance in Sub-Saharan Africa. NBER Working Paper 6562.

Romer, P. M., 1986, Increasing returns and long-run growth. Journal of Political Economy 94: 1002 - 1037.

Romer, P. M., 1990, Endogenous Technological Change. Journal of Political Economy 98: S71 - S102.

Ruttan, V. W., 1998, The New Growth Theory and Development Economics. A Survey. Journal of Development Studies 35, 2: 1 - 26.

Sachs, J. and A. Warner, 1995, Economic Reform and the Process of Global Integration. Brookings Papers on Economic Activity 1: 1 - 118.

Sachs, J. and A. Warner, 1997. Sources of Slow Growth in African Economies. Journal of African Economies 6 (3): 335 - 376.

Sala-i-Martin, X., 1997, I Just Ran Two Million Regressions. American Economic Review 87: $178-183$.

Segerstrom P. S., 1998, Endogenous Growth without Scale Effects. American Economic Review 88: 1290 - 1310.

Smulders, S., this issue, Convergence, Growth and the Welfare Gains of Capital Mobility. International Economics and Economic Policy 2/3.

Stokey, N., 1991, Human Capital, Product Quality, and Growth. Quarterly Journal of Economics 106: $587-661$.

Tang, P.J.G. and Wälde, K., 2001, International competition, growth and welfare. European Economic Review 45: 1439-1459.

Temple, J., 1999, The New Growth Evidence. Journal of Economic Literature 37: 112 156.

Wade, R., 1990, Governing the Market: Economic Theory and the Role of Government in East Asian Industrialization. Princeton, New Jersey: Princeton University Press.

Wälde, K., 1999, A Model of Creative Destruction with Undiversifiable Risk and Optimising Households. Economic Journal 109: C156 - C171 
Walz, U., 1995, Trade Liberalization, Factor Mobility, and Regional Growth. Journal of Institutional and Theoretical Economics 151: 505 - 525.

Walz, U., 1997, Growth and Deeper Regional Integration in a Three Country Model. Review of International Economics 5: 492 - 507.

Walz, U., 1998, Does an enlargement of a common market stimulate growth and convergence? Journal of International Economic 45: 297 - 321.

WTO, 2004, World Trade Report 2004. Geneva.

Vamvakidis, A., 2002, How robust is the growth-openness connection? Historical evidence. Journal of Economic Growth 7: 57 - 80

Yanikkaya, H., 2003, Trade openness and economic growth: a cross-country empirical investigation. Journal of Development Economics 72: 57- 89.

Young, A., 1998, Growth without Scale Effects. Journal of Political Economy 106: 4163. 